\title{
ANALYSIS AND DESIGN OF ACCOUNTING INFORMATION SYSTEM OF PURCHASE OF CREDIT SPARE PARTS IN PT. SUMBER BATU
}

\author{
Daniel Pangondian, Setyo Riyanto \\ Mercu Buana University, Jakarta, Indonesia \\ Mercu Buana University, Jakarta, Indonesia \\ Email: ddanieru@yahoo.co.id and setyo.riyanto@mercubuana.ac.id
}

\section{ARTICLE INFO}

Date received : 20 August 2020

Revision date : 01 November 2020

Date received : 11 November 2020

\section{Keywords:}

Information System Accounting

Credit Purchases

Internal Control Systems

\begin{abstract}
This research was conducted at PT. Sumber Batu which is engaged in contracting. Activities carried out by the company, one of which is the purchase of spare parts on credit. The implementation of the accounting system for purchasing spare parts on credit has not yet fully carried out activities in accordance with internal controls. Data collection was carried out using interview and observation techniques. The analysis conducted was a qualitative descriptive analysis by analyzing and designing Flowcharts, Data Flow Diagrams (DFD), Entity Relationship Diagrams (ERD), and Normalization. Based on research that has been done, researchers can draw the conclusion that there is no duplication of functions applied to the procedure for purchasing spare parts on credit.
\end{abstract}

\section{INTRODUCTION}

Anastasia Along with the development of increasingly sophisticated science and technology in this modern era, business competition between companies is getting tougher, so that every company is required to improve work quality, service quality, and data accuracy. In the corporate environment, information technology is needed to help facilitate operational activities to be effective and efficient in various aspects. (Anastasia Diana \& Lilis Setiawati, 2011)

Accounting information system (AIS) is a system where documents are produced through an integrated / interconnected process. In SIA, there are four types of systems in it, one of which is the expenditure cycle, which is events related to the acquisition of goods and services from other entities and the payment of related obligations. One part of the expenditure cycle is purchasing. (Anggita Putri, Mega, 2013). Whether it's purchasing raw materials for the type of manufacturing company or purchasing products for the type of trading company. Purchase transactions involve parts of demand (warehouse), purchases, receipts, accounts payable, finance, and accounting. (Bodnar \& Hopwood, 2004).

PT. Sumber Batu is a contracting company that has contributed to the development of various sectors such as the construction of highways, railways, docks, runways, tunnels and buildings. Many activities carried out by the company, one of which is the purchase of raw materials (stone ash, scrining, split), asphalt, fuel oil, and spare parts. Purchasing activities carried out by PT. Sumber Batu to support production which aims to meet consumer needs.

The design of accounting information systems for credit purchases and good internal control will give good results. Therefore, the author would like to research a purchasing accounting information system with the title "Analysis and Design of Accounting Information Systems of Purchasing Spare Parts in Credits in. PT Sumber Batu ". The purpose of writing this thesis is:

1. To find out the accounting information system for credit purchases applied to PT. Sumur Batu.

2. To find out the accounting information system for credit purchases applied to PT. Sumber Batu is in accordance with the Internal Control System (SPI).

3. To make the design of accounting information systems for purchasing credit at PT. Sumur Batu. 


\section{METODE}

The object of research used by the author is PT. Sumber Batu whose business activities are engaged in the contractor having its address at $\mathrm{Jl}$. Raya Bekasi Km 23,5 Cakung - East Jakarta.

Data in the form of primary data sourced from PT. Sumur Batu. The data used are qualitative data consisting of:

a. A brief history of PT. Sumur Batu

b. The organizational structure of PT. Sumur Batu

c. Purchasing documents used by PT. Sumur Batu

d. PT. Sumur Batu

Data collection methods used to obtain and support the writing of this thesis are interviews with the parties concerned in this case the parts of the company that carry out activities related to credit purchases and make observations by observing directly an activity that is being carried out related to the credit purchase system .

The analytical tool used is a qualitative description analysis that is an analysis using data obtained by the author then compared with theories. Based on the analysis that has been made, then the writer tries to give a proposed solution. The stages are as follows:

1. System Analysis

Conduct an investigation (initial inspection) and system survey to collect data about the accounting system for credit purchase transactions at PT. Sumur Batu.

2. System Design

This stage designs the system by making flowcharts, Data Flow Diagrams (DFD), Entity Relationship Diagrams (ERD), and normalization.

\section{RESULTS AND DISCUSSION}

A. Credit Spare Parts Purchasing System Procedures Applied by PT. Sumur Batu

1. Warehouse Section

The warehouse section checks the stock of goods, if the stock of goods in the warehouse has reached a minimum stock, then the head of the warehouse makes a Request for Goods (SPB) of 2 sheets, SPB sheet 1 is submitted to the purchasing department and SPB sheet 2 is archived permanently.

2. Purchasing department

Receive SPB sheet 1 from the warehouse, then the purchase makes a Purchasing Order (PO) of 4 sheets, PO sheet 1 is given to suppliers, PO sheet 2 to the accounting department, $P O$ sheet 3 is archived, and PO sheet 4 to the goods receipt section.

After the goods are received, the purchasing department receives LPB sheet 1 from the receipt of goods and the Invoice completed with SJB and PO sheet 1 from suppliers to be matched between PO sheets 3 and SJB from suppliers, then recorded on the Debt Card. After that, 3 sheets of Invoice Receipt (TTF), sheet 1 TTF is given to the supplier, sheet 2 TTF along with the Debt Card, Invoice, SJB, and sheet $1 \mathrm{PO}$ is given to the financial department, and sheet 3 TTF is archived permanently.

3. Goods Receipt Section

The receipt of goods receives $\mathrm{PO}$ sheet 4 from the purchase. Then the receipt of goods matches the goods sent by the supplier between the Goods Road Letter (SJB) and PO sheet 4. After that make a Goods Receipt Report (LPB) of 3 sheets, LPB sheet 1 to the purchase section, LPB sheet 2 to the accounting department, LPB sheet 3 to the fixed archived section and $\mathrm{SJB}$ is given to the supplier to match it back to the purchasing section.

4. Financial department

The finance department accepts TTF sheet 2 accompanied by Debt Cards, Invoices, SJB, and PO sheets 1 of the subsequent purchase section checked and matched. Then the finance department opens demand deposits according to the due date (45 days after the TTF is received by the purchasing department). When demand deposits received by suppliers are disbursed according to the due date, the financial department makes 2 pieces of Cash Proof $(B K), 1$ sheet $B K$ is given to the accounting department, 2 sheet $\mathrm{BK}$ is given to the supplier, and 2 sheet TTF along with Invoice, SJB, PO sheet 1 is archived fixed, and the Debt Card is given back to the purchasing department.

5. Accounting Section

Receive $P O$ sheet 2 from the purchasing department, LPB sheet 1 from the goods receipt section, and $B K$ sheet 1 from the financial department. Then the accounting department will do the journaling. 


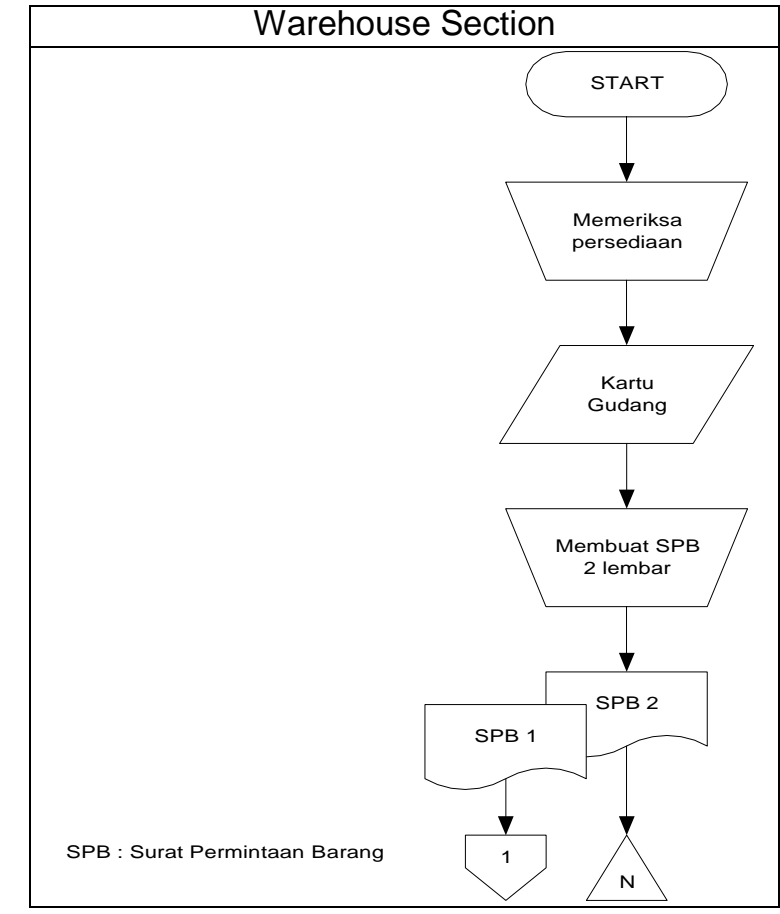

Figure 4.1 Credit Purchase Procedures in the Warehouse Section

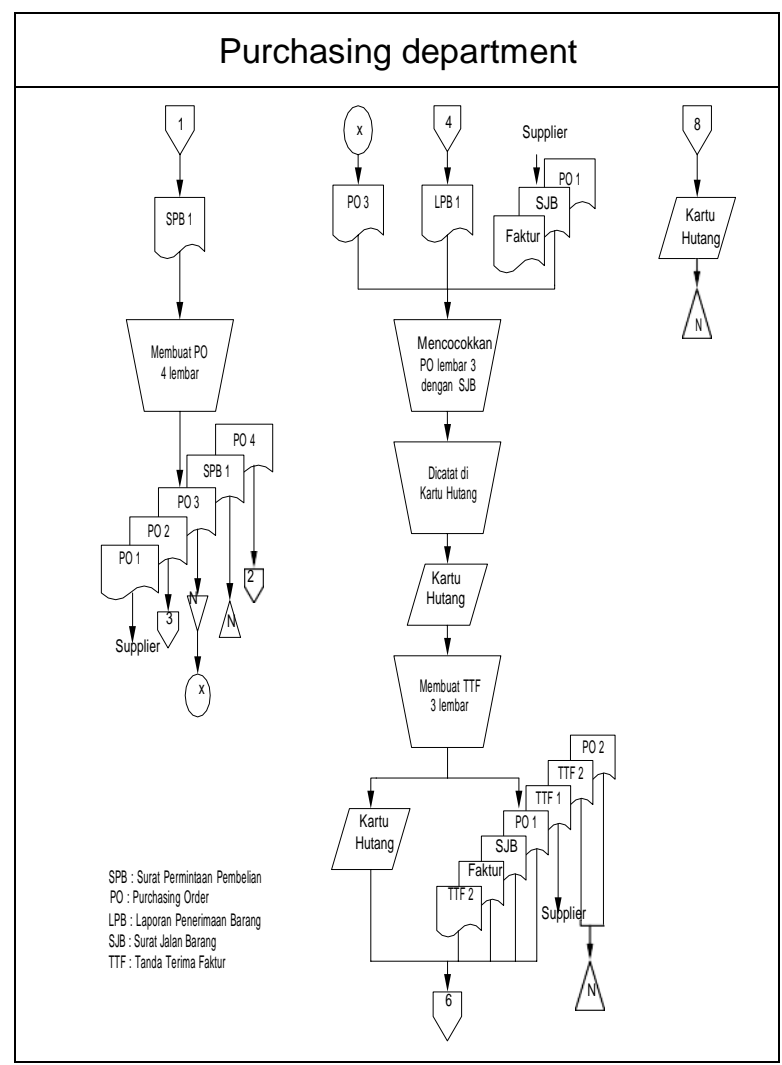

Figure 4.2 Credit Purchasing Procedures in the Purchasing Section

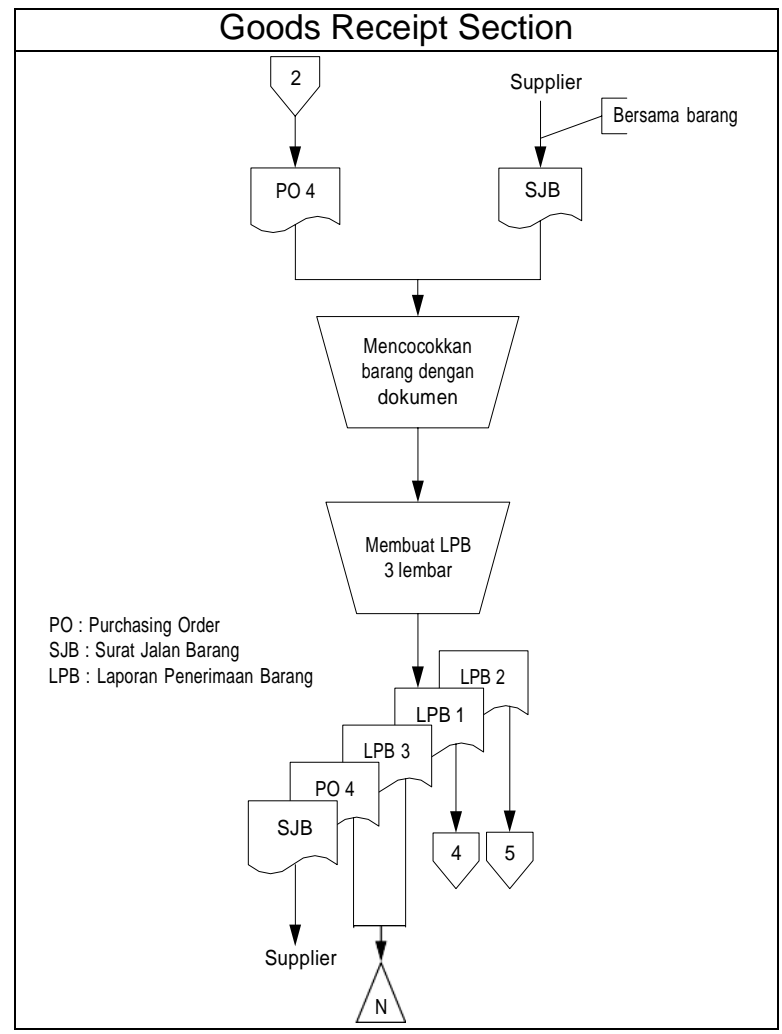

Figure 4.3 Credit Purchase Procedures in the Goods Receipt Section

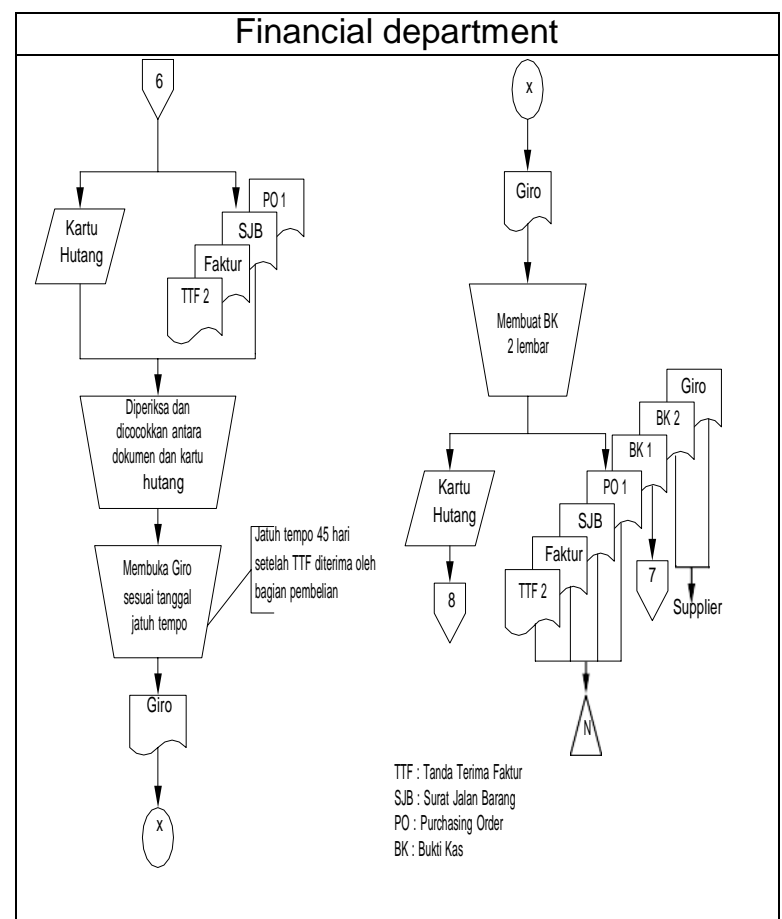

Figure 4.4 Credit Purchasing Procedures in the Financial Bgaian 


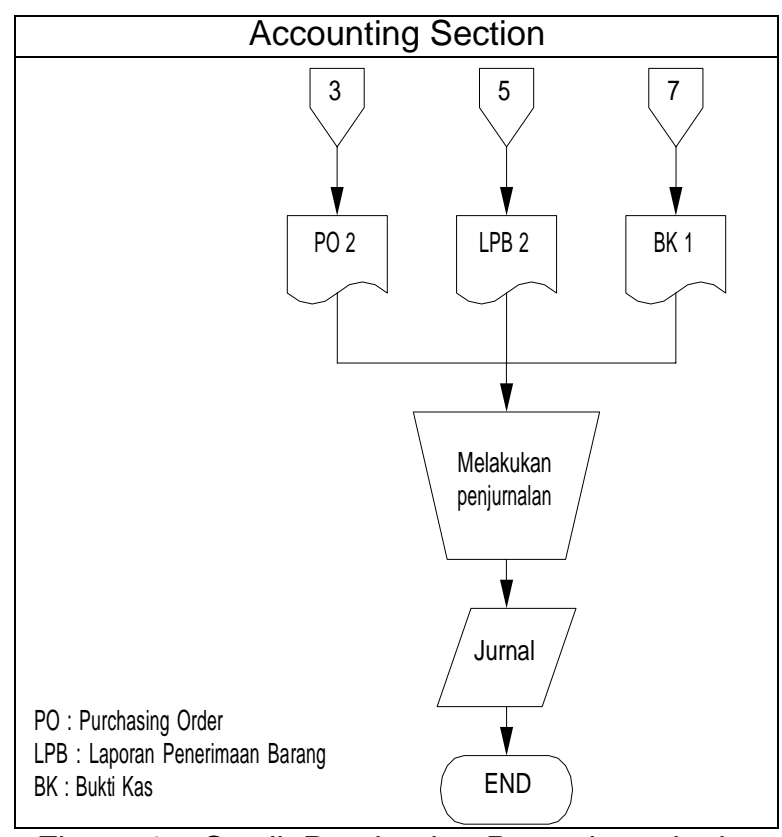

Figure 4.5 Credit Purchasing Procedures in the Accounting Section

\section{B. Purchasing Internal Control System}

After the authors examined PT. Sumber Batu and analyzing the accounting information system for purchasing spare parts on credit, the authors found that there is no concurrent function applied to the purchasing system for spare parts on credit. But there are weaknesses of the basic elements of internal control in purchasing spare parts on credit that are applied to PT. Stone Resources are:

Table 4.1

Deviations from the Elements of the Internal Control System Hall (Hall, 2001)

\begin{tabular}{|c|c|c|}
\hline No. & SPI elements & $\begin{array}{l}\text { Form of Activity } \\
\text { Irregularities }\end{array}$ \\
\hline 1 & $\begin{array}{l}\text { Authorization } \\
\text { System and } \\
\text { Recording } \\
\text { Procedure }\end{array}$ & 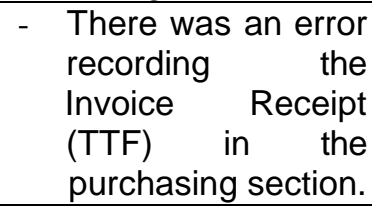 \\
\hline 2 & $\begin{array}{l}\text { Healthy } \\
\text { Practices }\end{array}$ & 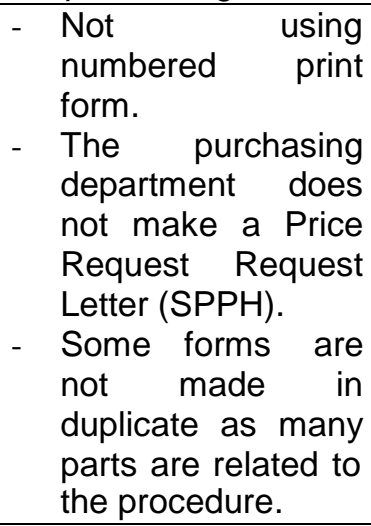 \\
\hline
\end{tabular}

\section{SIA Evaluation of Credit Purchases at PT. Sumur Batu}

After the authors know the procedures and accounting systems that run on PT. Sumber Batu, the authors evaluate that:

1. There are 5 functions in the credit purchase system at PT. Sumber Batu, namely the warehouse function, purchasing function, revenue function, financial function, and accounting function.

2. Information system purchasing procedures for spare parts on credit at PT. Sumber Batu has gone well.

3. The purchasing department does not make a Price Request Request Letter (SPH).

4. The receipt of goods does not copy the invoice as much as the part related to the procedure received from the supplier.

5. The receipt of goods does not give the goods to the warehouse for storage.

\section{Proposed Credit Part Purchase System} Procedure

1. Warehouse Section

The warehouse section checks the stock of goods, if the stock of goods in the warehouse has reached a minimum stock, then the head of the warehouse makes a Request for Goods (SPB) of 2 sheets, SPB sheet 1 is submitted to the purchasing department and SPB sheet 2 is archived permanently.

2. Purchasing department

Receive SPB sheet 1 from the warehouse, then the purchase makes a Request for Price Request (SPPH) of 1 sheet given to suppliers. After getting the Price Offer Letter (SPH) from the supplier, then this part makes a purchase order for goods in the form of spare parts that will be ordered by making a Purchasing Order (PO) of 5 sheets, PO sheet 1 sent to the supplier, PO sheet 2 to the accounting department, PO sheet 3 , SPB sheet 1 , and SPH are fixed, PO sheet 4 to the receipt of goods, and $P O$ sheet 5 to the financial section.

3. Goods Receipt Section

The receipt of goods receives $\mathrm{PO}$ sheet 4 from the purchase. Then receive goods sent from suppliers that are accompanied by a Goods Road Letter (SJB) and Invoice, then match PO sheet 4, SJB, and Invoice with goods received. After that the receipt of goods copies the invoice given by the supplier as many as 3 sheets for archiving. After that, the receipt of goods makes a 4-page Goods Receipt Report (LPB), sheet 1 LPB and copy of invoice 1 with goods given to the warehouse, sheet 2 
LPB and copy 2 invoices to the accounting department, sheet 3 LPB, original invoice, PO sheet 4 , and the SJB is archived, LPB sheet 4 is given to suppliers, and invoice copy 3 to the finance department.

4. Financial department

After receiving a copy of invoice 3 from the receipt of goods, payment will be made based on the due date by first matching the copy of invoice 3 with PO sheet 5 . After that making 2 pieces of Cash Proof (BK), 1 sheet BK accompanied by sheet $5 \mathrm{PO}$ and copy of invoice 3 will be archived fixed, BK sheet 2 is given to the accounting department to record.

5. Accounting Section

The accounting department receives $\mathrm{PO}$ sheet 2 from the purchasing department, LPB sheet 2 and invoice copy 2 from the goods receipt section, as well as BK sheet 2 from the finance section. After that the documents are matched and then journalizing, then filing the documents.

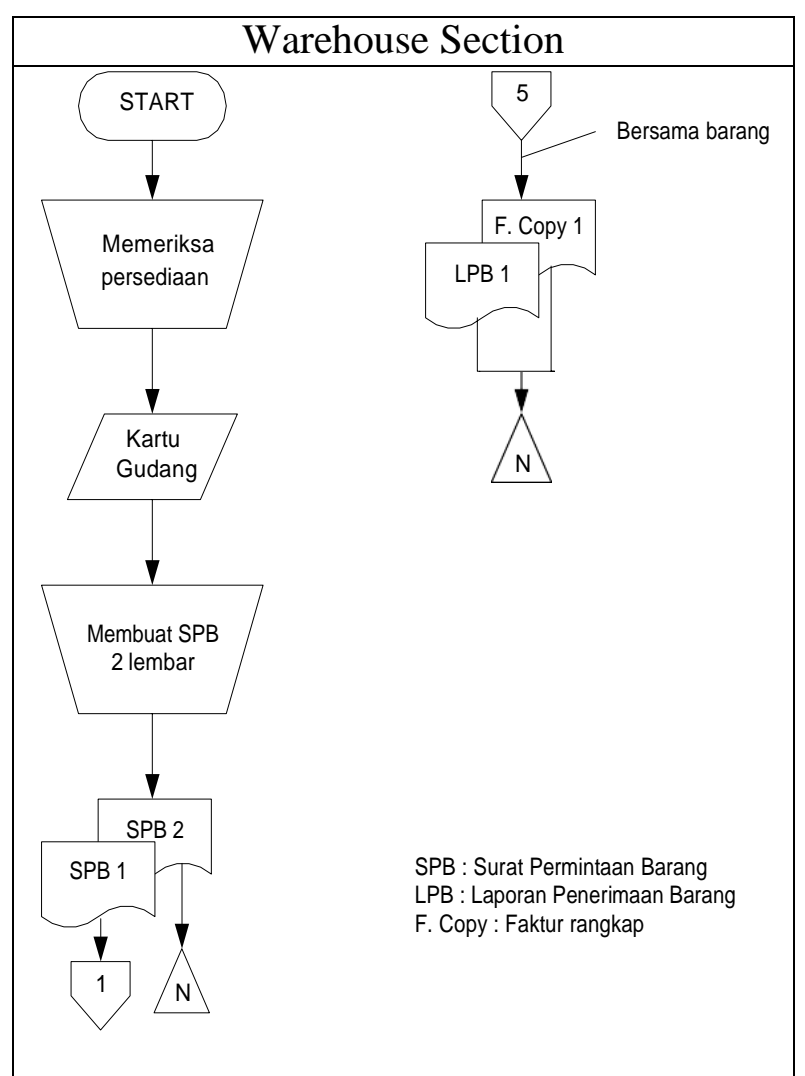

Figure 4.6 Proposed Credit Purchase Procedure in the Warehouse Section

Purchasing department

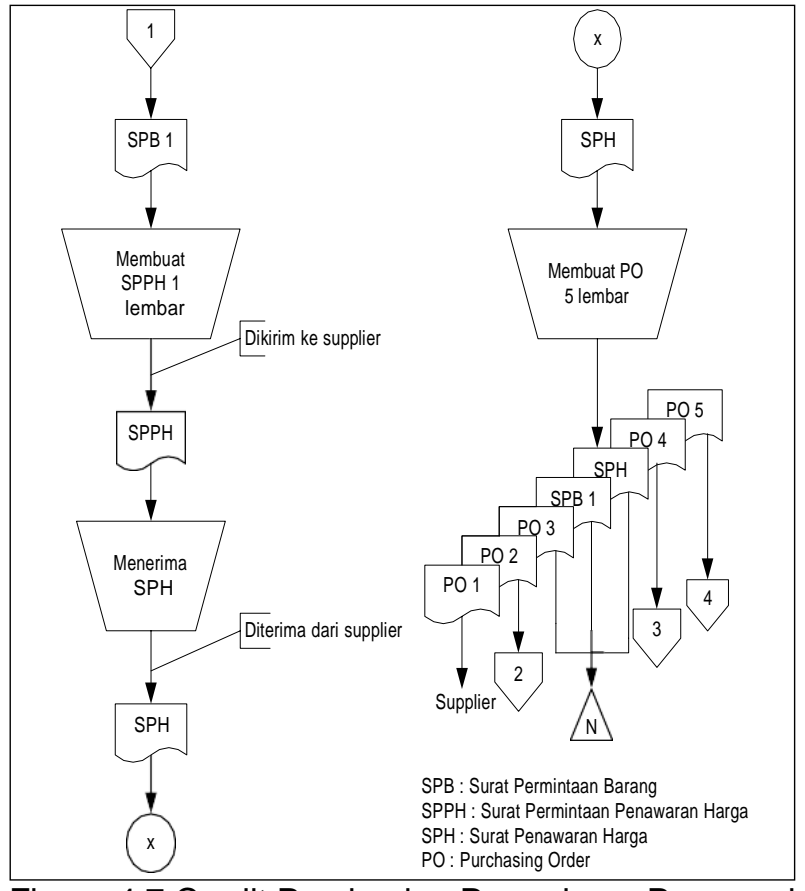

Figure 4.7 Credit Purchasing Procedures Proposed In the Purchasing Section

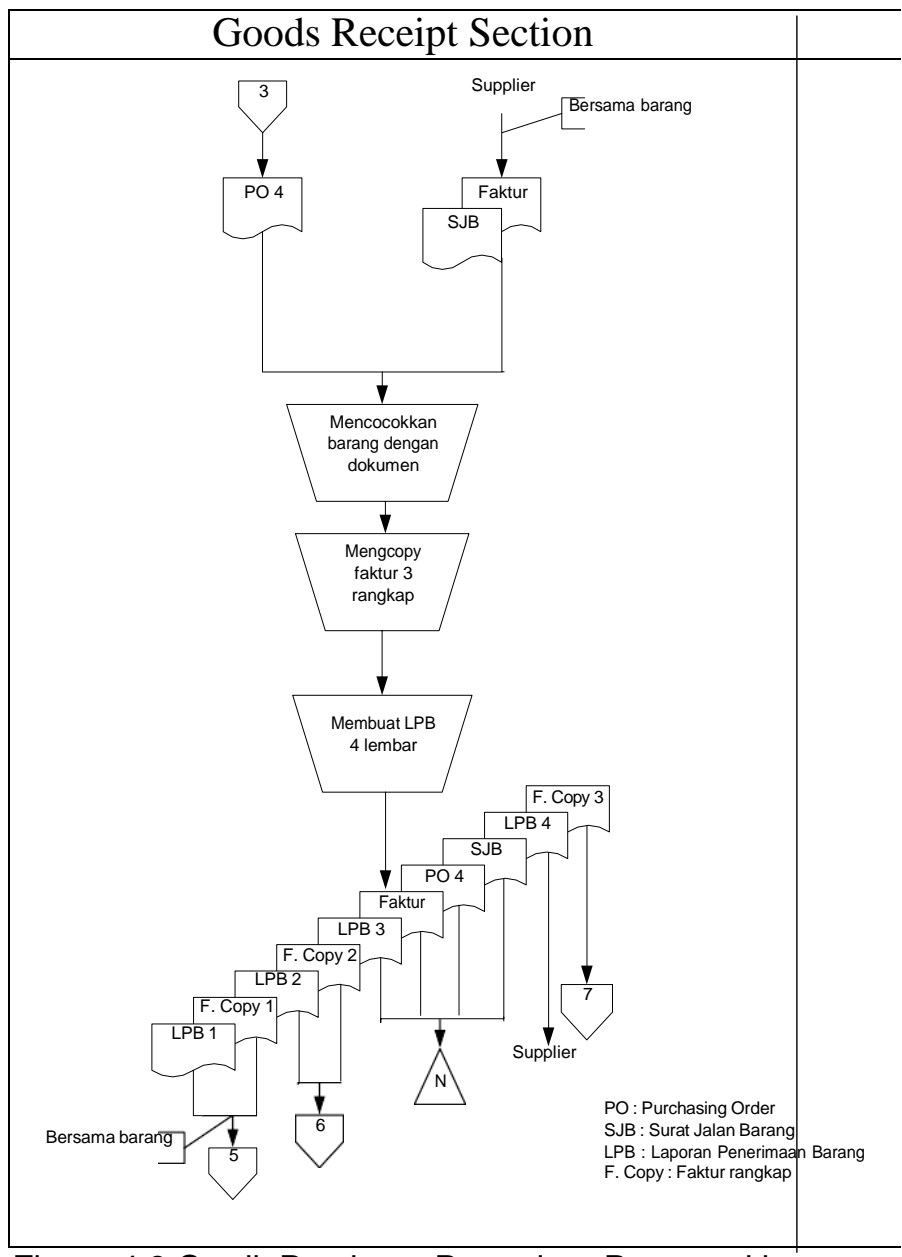

Figure 4.8 Credit Purchase Procedure Proposed in the Goods Receipt Section 


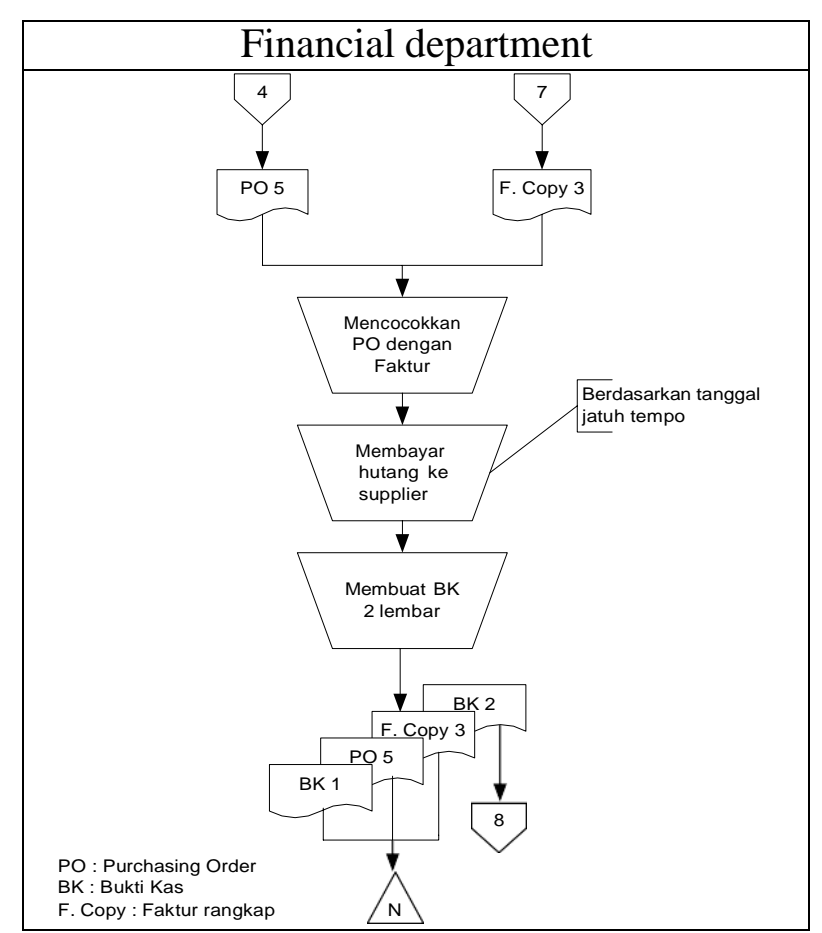

Figure 4.9 Credit Purchase Procedures Proposed in the Financial Section

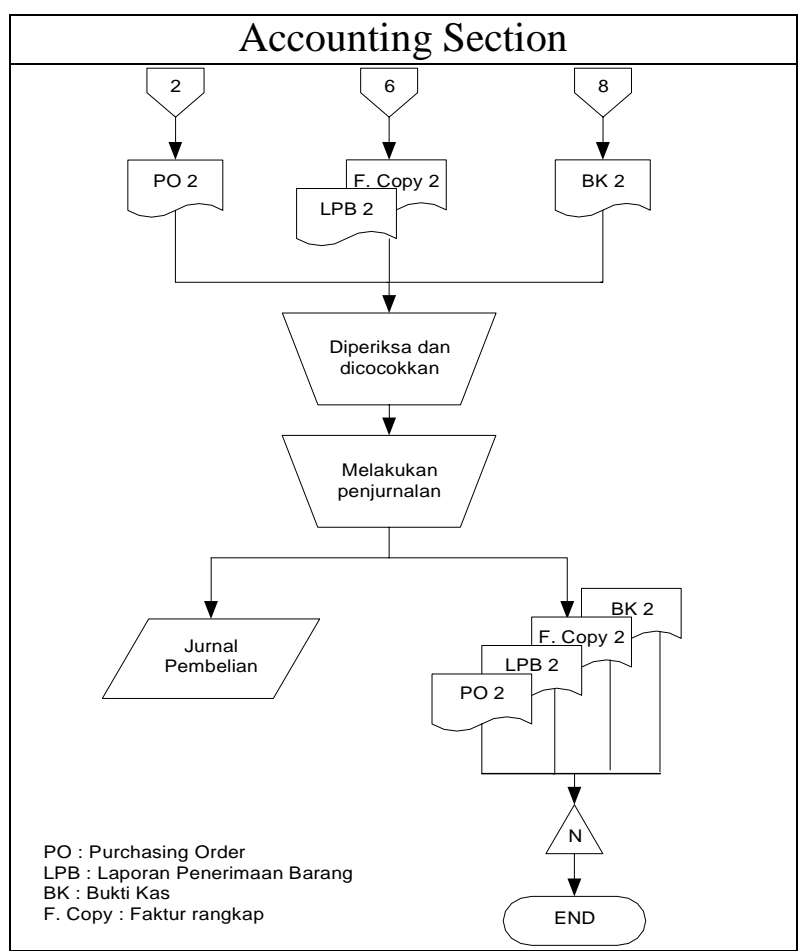

Figure 4.10 Credit Purchase Procedures Proposed in the Accounting Section

\section{E. The Logic Model of the Proposed Credit Purchase System}

1. Context Diagram

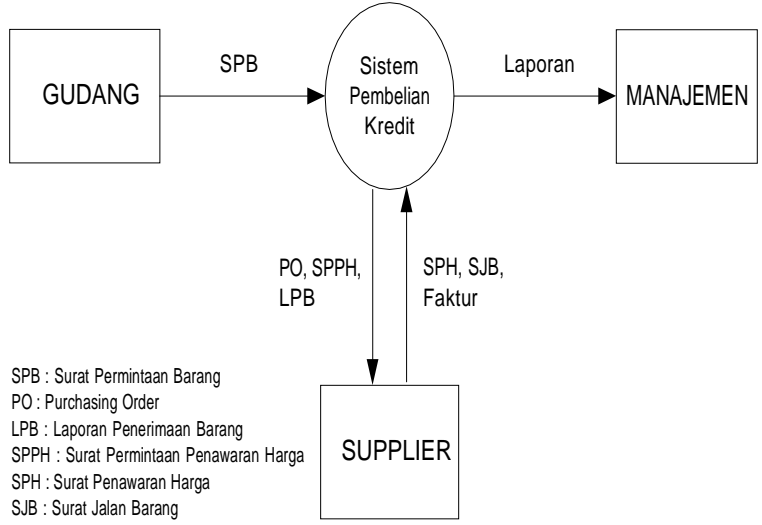

Figure 4.11 Context Diagram

2. Zero diagram

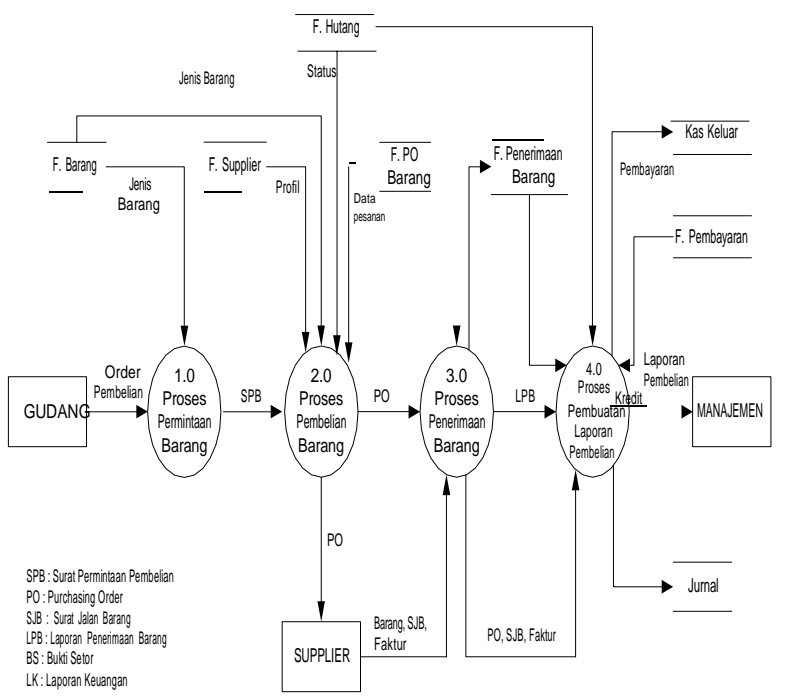

Figure 4.12 Zero Diagram

3. Level Diagram

a. Level 1 Process 1

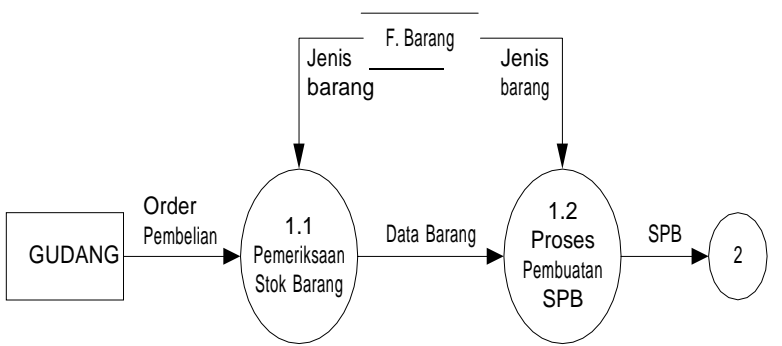

Figure 4.13 Process 1 Level 1 Diagram 
b. Level 1 Process 2

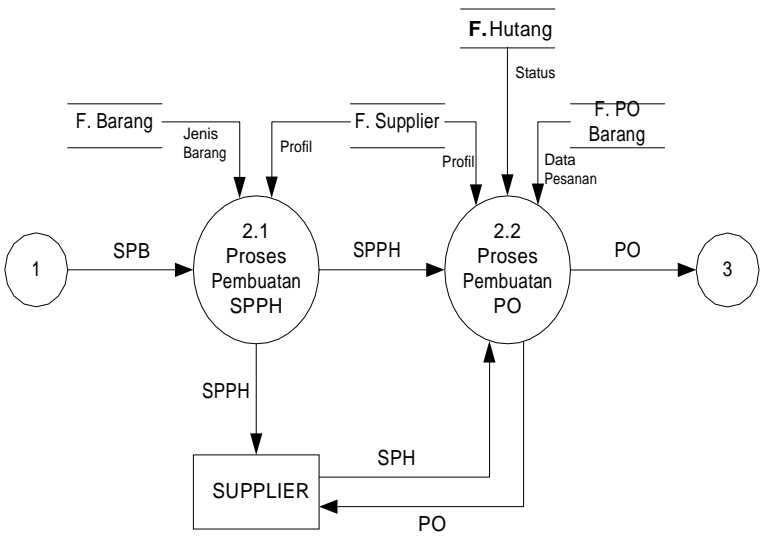

Figure 4.14 Process Level 1 Diagram 2

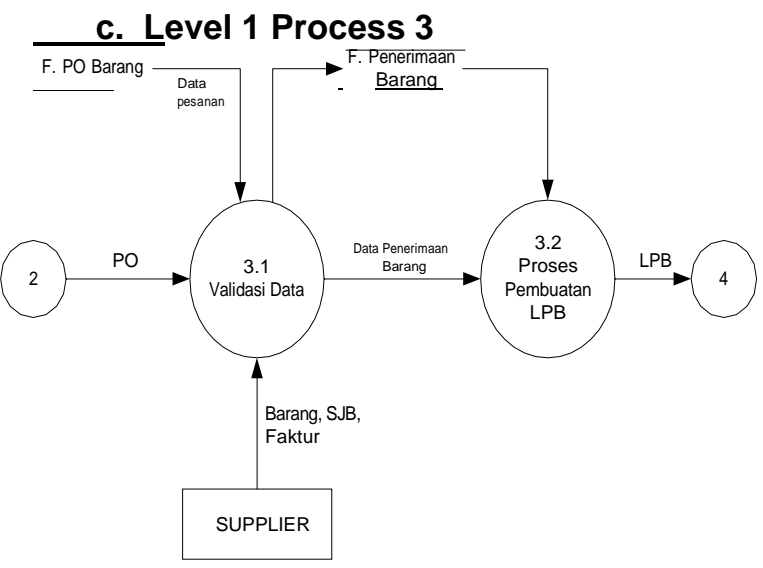

Figure 4.15 Lebel 1 Process Diagram 3

\section{d. Level 1 Process 4}

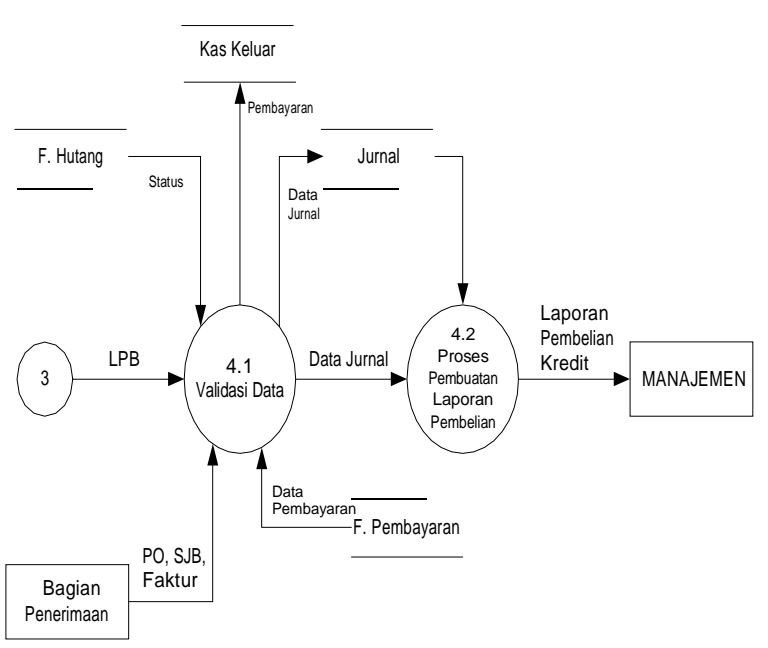

Figure 4.16 Level 1 Process Diagram 4

\section{F. Entity Relationship Diagram (ERD)}

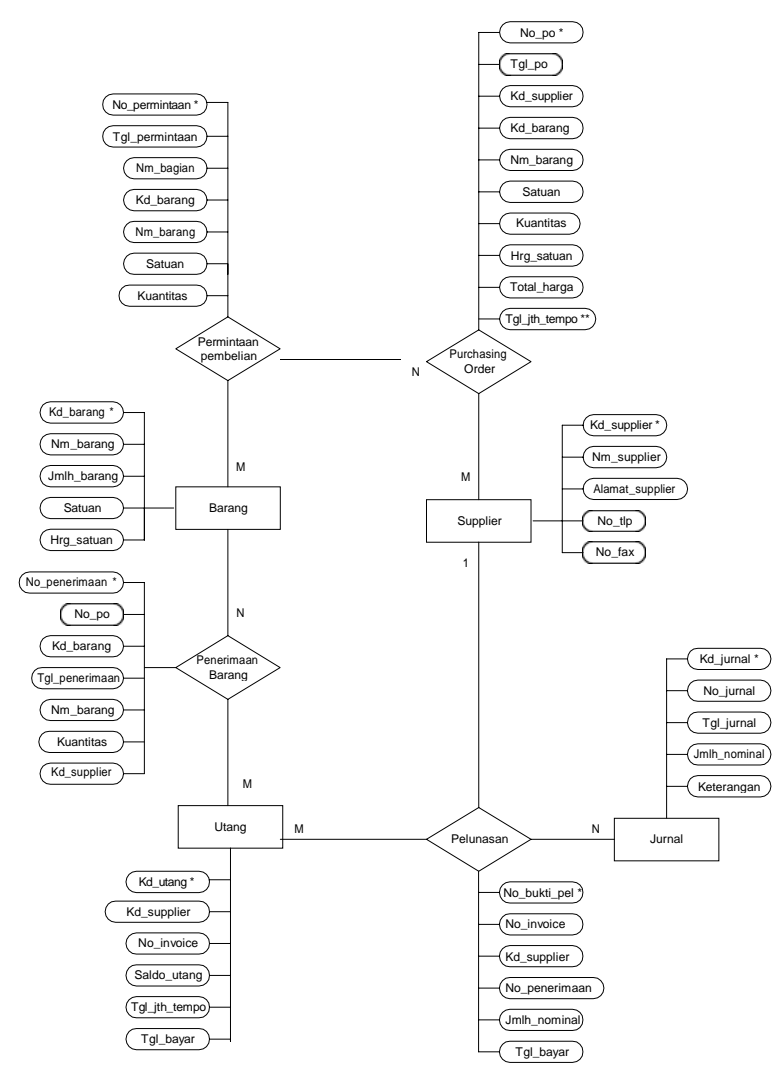

Figure 4.17 Entity Relationship Diagram

G. Normalization

1. Abnormal Forms / Unnomalized Form (UNF)

Table 4.2

\section{Abnormal Forms}

\begin{tabular}{|c|c|}
\hline Item & Credits \\
Item & Kd_supplier \\
Numberof items & No_invoice \\
Unit & Debt_ow \\
Unit_r & Date_jth_tempo \\
No_request & Date_paid \\
Date_questions & No_bukti_pel \\
Nm_part & No_invoice \\
Item & Kd_supplier \\
Item & No_address \\
Unit & Number of numbers \\
Quantity & Date_paid \\
No_po & Kd_jurnal \\
Date_po & No_jurnal \\
Kd_supplier & Date dated \\
Item & Number of numbers \\
Item & Information \\
Unit & No_address \\
Quantity & No_po \\
Unit_r & Item \\
Total price & Reception_date \\
Date_jth_tempo & Item \\
Kd_supplier & Quantity \\
Nm_supplier & Kd_supplier \\
SUPPLY_address & \\
No_tlp & \\
& \\
\hline
\end{tabular}




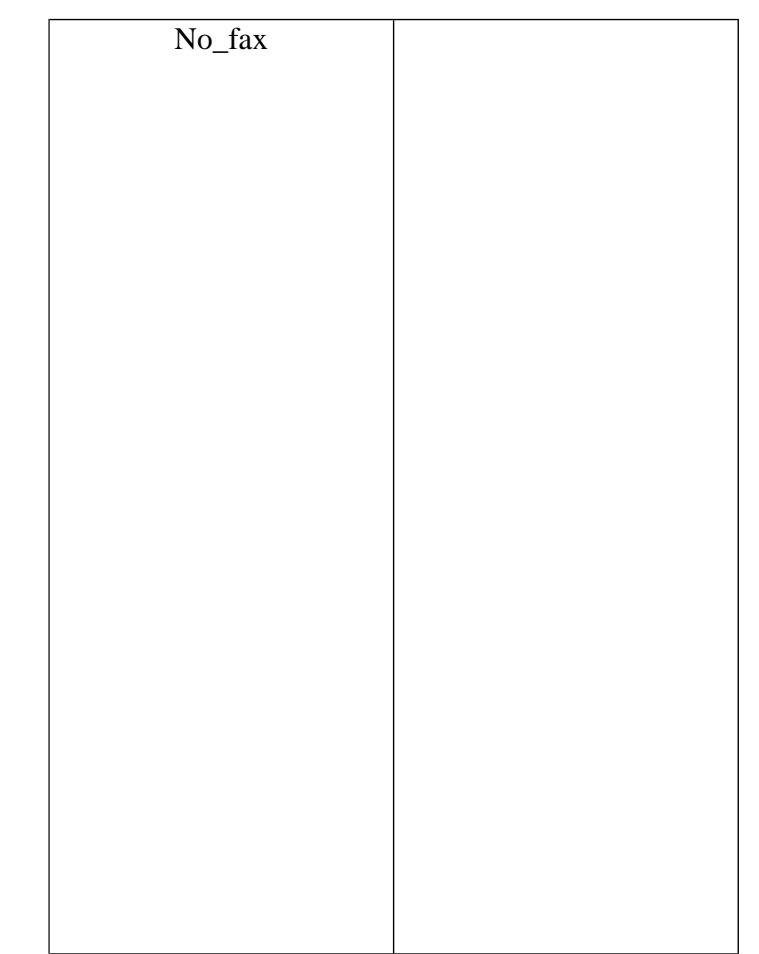

\section{First Normal Form (1NF)}

Table 4.3

First Normal Form (1NF)

\begin{tabular}{|c|}
\hline GOODS \\
\hline Item \\
Item \\
Number of \\
items \\
Unit \\
Unit_r \\
\hline
\end{tabular}

\section{PURCHASIN \\ G ORDER}

No_po

Date_po

Kd_supplier

Item

Item

Unit

Quantity

Unit_r

Total price

Date_jth_tempo

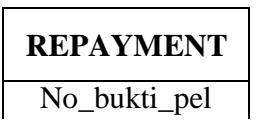

\begin{tabular}{|c|}
\hline SUPPLI \\
ER \\
\hline Kd_supp \\
lier \\
Nm_sup \\
plier \\
SUPPLY \\
address \\
No_tlp \\
No_fax \\
\hline
\end{tabular}

\begin{tabular}{|c|}
\hline REQUEST \\
PURCHASE \\
\hline No_request \\
Date_questions \\
Nm_part \\
Item \\
Item \\
Unit \\
Quantity \\
\hline
\end{tabular}

GOODS

No_addr

ess

No_po

Item

Receptio

n_date

Item

Quantity

Kd_supp lier

\begin{tabular}{|c|}
\hline JOURN \\
AL \\
\hline Kd_jurna \\
1 \\
No_jurna \\
1 \\
Date \\
dated \\
Number
\end{tabular}

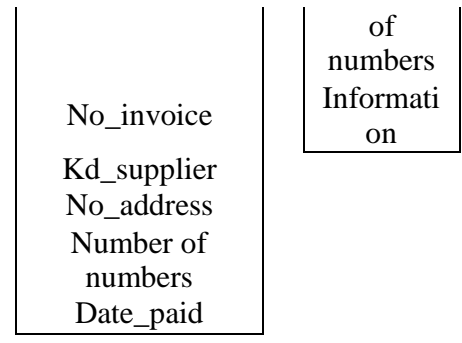

3. Second Normal Form (2NF)

Table 4.4

Second Normal Form (2NF)

\begin{tabular}{|c|}
\hline GOODS \\
\hline Item * \\
Item \\
Number of \\
items \\
Unit \\
Unit_r \\
\hline
\end{tabular}

\begin{tabular}{|c|}
\hline $\begin{array}{c}\text { PURCHASIN } \\
\text { G } \\
\text { ORDER }\end{array}$ \\
\hline No_po * \\
Date_po
\end{tabular}

Kd_supplier **

$$
\begin{gathered}
\text { Item } * * \\
\text { Item } \\
\text { Unit }
\end{gathered}
$$

Quantity

Unit_r

Total price

Date_jth_tempo

\begin{tabular}{|c|c|}
\hline REPAYMENT & $\begin{array}{c}\text { No_jurnal } \\
\text { Date dated } \\
\text { Number of } \\
\text { numbers } \\
\text { Information }\end{array}$ \\
No_bukti_pel *
\end{tabular}

No_address

No_po **

Item $* *$

Reception_d ate

Item

Quantity

Kd_supplier **

JOURNAL

Kd jurnal *

No_jurnal

Date dated

\begin{tabular}{|c|c|}
\hline DEBT & No_1nvolce \\
\hline Credits & Kd_supplier ** \\
\hline Kd_supplier & \\
\hline $\begin{array}{l}\text { No_invoice } \\
\text { Debt_ow }\end{array}$ & $\begin{array}{l}\text { Number of } \\
\text { numbers } \\
\text { Date_paid }\end{array}$ \\
\hline
\end{tabular}

numbers

\begin{tabular}{|c|}
\hline REQUEST \\
PURCHAS \\
E \\
\hline Request_No \\
$*$ \\
Date_questio \\
ns \\
Nm_part \\
Item ** \\
Item \\
Unit \\
Quantity \\
\hline
\end{tabular}

\section{DEB T \\ Account Debt * \\ Kd_supplier \\ No_invoice \\ Debt_ow \\ Date_jth_te mpo \\ Date_paid}




\section{CONCLUSION}

Based on the analysis and data collection that has been done by the author, the writer can draw the following conclusions:

Accounting information system for purchasing spare parts on credit that is running at PT. Sumber Batu has 5 functions, namely warehouse function, purchase function, revenue function, financial function, and accounting function. This separation of functions has been carried out in accordance with the internal control system.

Accounting information system for purchasing spare parts on credit at PT. Sumber Batu in general has been carried out in accordance with existing procedures in terms of the theoretical basis, but still has weaknesses:

a. There was an error recording the Invoice Receipt (TTF) in the purchasing section.

b. Not using numbered print form.

c. The purchasing department does not make a Price Request Request Letter (SPPH).

d. Some forms are not made in duplicate as many parts are related to the procedure.

The design of accounting information systems created using flowcharts, Data Flow Diagrams (DFD), Entity Relationship Diagrams (ERD), and normalization.

Based on the conclusions above, the author tries to give suggestions that might be used by PT. Sumber Batu as a consideration for improving internal control over the credit spare parts purchasing system, as follows:

So that the accounting information system for purchasing spare parts on credit can run well, it is better for the recording of Invoice Receipt (TTF) to be done by the finance department because the form is related to finance. A Price Quotation Request (SPPH) was made at the purchasing department to request a supply of goods so that procurement of goods at high prices can be avoided.

In order for internal control to be well organized, PT. Sumber Batu applies the elements of internal control starting from the separation of duties and clear responsibilities, authorization and recording procedures so that the company's wealth will be guaranteed security and recorded accounting data guaranteed accuracy, sound practices are actually applied in each system so that the company's goals will be can be achieved effectively and efficiently.

Need to make improvements to the current system at PT. Sumber Batu in order to support the effectiveness of internal control.

\section{REFERENCES}

Anastasia Diana, Lilis Setiawati. 2011. Accounting Information Systems, Design, Process and Application. First Edition. Yogyakarta: Andi Yogyakarta.

Anggita Putri, Mega. 2013. Purchasing Accounting Information Systems in Joint Forward Cooperatives. Jakarta: Economics of Gunadarma University.

Bodnar, George H and Williams S, Hopwood, translated by Julianto Agung Saputro. 2006. Accounting Information Systems. Ninth Edition. Yogyakarta: Andi Yogyakarta.

Hall, James, A. 2001. Accounting Information Systems. Third Edition. Jakarta: Salemba Empat.

Hartono, Jogiyanto. 2005. Analysis and Design of Information Systems (Structured Approach to Business Application Theory and Practice). Yogyakarta: Andi Yogyakarta.

Lumbangaol, Linduben. 2013. Analysis and Design of Accounting Information Systems for Purchasing Credit at Yamaha Sinar Harapan Motor. Jakarta: Economics of Gunadarma University.

Marlinda, Linda, S.Kom. 2004. Database Systems. Yogyakarta: Andi.

Mulyadi. 2001. Accounting System. Issue 3. Jakarta: Fourth Salemba.

Mulyadi. 2008. Accounting System. Jakarta: Salemba Empat.

Romney, Marshall B., and Steinbart, Paul. 2006. Accounting Information System. Book One, Ninth Edition. Jakarta: Salemba Empat.

Susmiyanti, Mia. 2007. Analysis of Accounting Information Systems for Purchasing Raw Materials in Cash in Relation to Purchasing Management Decision Making at PT. Vigano CiptaPerdana. Jakarta: Economics of Gunadarma University.

Wuri Al, Fefi. 2012. Analysis of Accounting Information Systems for Purchasing Raw Materials in Cash to Increase the Effectiveness of Internal Control at PT. Dwi Mulyo Lestari Madiun. Volume 1. Number 1. Madiun: Accounting Education IKIP PGRI Madiun.

ZsaZsa, Yaumil. 2011. Analysis and Design of Accounting Information Systems for Cash 


\section{Copyright holder:}

Daniel Pangondian, Setyo Riyanto (2020)

First publication right :

Journal of Social Science

\section{This article is licensed under:}

(c) (i) (2) 